\title{
ROAR OF THE LION IN \\ LITERARY JUNGLES OF \\ NUSANTARA
}

\section{Hadijah Rahmat}

hadijah.rahmat@nie.edu.sg

National Institute of Education,

Nanyang Technological University,

Singapore.

Tel.: +6567903523

\begin{abstract}
This article highlights the connection between Malay literature in Singapore and the literature of Malaysia and other nations of Nusantara, the Malay world. It examines effects of the political separation of 9 August 1965 on Malay literature in Singapore. Has separation of almost 50 years truly severed ties between Malaysia and Singapore as far as Malay literature is concerned? Do Malay literary works reflect a divide between the cultures of Malaysia and Singapore? Is there still continuity in the spirit of a common origin? This article attempts to answer these questions through discussion on the developments in a shared literature before 1965, effects and themes of "separation" in the literary works, phases in the development of literature since 1965, as well as patterns of literary connection between Malaysia and Singapore.
\end{abstract}

Keywords: Malay literature in Singapore, classical Malay literature, literary bonds, political separation, roar of the lion, jungles of Nusantara, spirit of common origin 
Politics may separate us, maps may impose boundaries on us, passports may prevent us from entry and exit, but culture will always unite us; language and literature transcend all this because they are the inward voices that bring together the conscience of the people of Nusantara.

(Usman Awang, 1978) ${ }^{1}$

\section{INTRODUCTION}

There is a close historical connection between Singapore and Malaysia and other countries of the Malay world, Nusantara. Singapore was once a part of Malaya/Malaysia and the Malay world. It had an important role, at least in the literature of the region. However, political ties between Singapore and Malaysia were abruptly severed on 9 August 1965 when Singapore seceded from Malaysia. What were the effects of this political separation on Malay literature?

Has the political separation of almost 50 years really and truly severed the ties of Malay between Malaysia and Singapore? Has the separation resulted in Malay literature in Malaysia being more developed than that of Singapore? Does the bond of shared cultural roots still exist in works produced? Do literary works reflect a divide between the culture of the Malays of Malaysia and Singapore? Does a continuity of the spirit of common origin still remain, and if it does, what is its mould and feel?

The article attempts to answer some of these questions. It consists of five parts:

1. The development of literature before 1965

2. Effects and the theme of "Separation" in literary works

3. The development of literature after 1965

4. The ties that bind the literature of Singapore-Malaysia

5. Comparison of works and Conclusion 


\section{A COMMON HISTORY - MALAY LITERATURE IN SINGAPORE BEFORE 1965}

Before such an attempt, let us revisit the past to view the history of the development of Malay literature that was centred in Singapore before 1965 . In fact the history goes a long way back and an attempt will be made to condense it in accordance with important stages in order to view Singapore's paths of development, role and contributions in the course of development of Malay literature.

Prior to the separation from Malaysia, the development of Malay literature can be divided chronologically into five mainstages:

1. Classical Period (13th-14th centuries)

2. British Colonization Period (1819-1900)

3. Pre-war Period (1900-1945)

4. Post-war Period (1945-1957)

5. Independence Period (1957-1965)

\section{STAGE 1- ROAR OF THE LIONIN CLASSICAL MALAY TEXTS ${ }^{2}$}

Singapore first appears in the pages of historical literature in the 13th century CE as the kingdom of Temasik. The classic, Sejarah Melayu (Malay Annals), which focuses on the glory days of the Melaka (Malacca) sultanate devotes a wide coverage on the kingdom of Temasik of the 13th and 14th centuries $\mathrm{CE}$, as one of the Malay kingdoms with a close relationship with the Melaka sultanate. The "roar" of Singaporean literature was first heard when the ruler of Palembang, Sang Nila Utama or Sri Teri Buana landed on the island of Temasik in 1299, and established a new kingdom after leaving Palembang, Sumatra. Several interesting episodes in Temasik are presented in this literary classic, indicating the extent of attention on Singapore, and the connection of this island to the history of the Melaka sultanate in general, particularly in Sumatra and the Malay Peninsula.

Sejarah Melayu explains that although Sri Teri Buana, the first Malay king, established his kingdom at Bukit Seguntang, Palembang, Sumatra, he had no wish to remain there for too long. Instead, he was drawn by the beauty of Temasik with "its exceptionally white sands stretching out" 
(Abdul Samad Ahmad, 1986:38), that he felt compelled to cross over along with his entourage, braving the southwesterly winds and immense waves, and even going so far as to throw the royal crown into the ocean to land on the island and and establish Temasik. The king was convinced that Temasik was special as a state, especially when he saw a lion-an animal known for its bravery-on the island. Thus he decided to establish his kingdom there and renamed it "Singapura" (Lion City).

After this historical event,

Negeri Singapura pun telah sudahlah diperbuat orang dengan kota paritnya, dan dengan segala istana dan balairung dalam dan balairung luar, serta sekalian rumah orang, kedai dan pasar; terlalu indah perbuatan negeri Singapura itu.

"The people built the kingdom of Singapore, with a fortress and moat, and palaces and audience halls, and homes for its people, shops and markets; so beautifully constructed was the kingdom of Singapore"

(A. Samad Ahmad, 1986:41).

\section{Early Signs of The Rise and Fall of Malay Glory}

The great epic Hikayat Hang Tuah, although centered on legends of the struggles of an exceptional Malay warrior of the 15th century Melaka sultanate prior to the arrival of Western powers sets Singapore as the backdrop of the life and struggles of this important and highly symbolic figure. Almost every crucial stage of Hang Tuah's life is narrated as having occurred in Singapore. Hang Tuah and his four friends encounter pirates in the Straits of Singapore as children, and the pirates are defeated due to the good-fortune, bravery and wisdom of the five friends. Hang Tuah's greatness and remarkable initial success of Hang Tuah as a child is is witnessed by Batin Singapura, who reports the incident to Bendahara Bentan, whose authority extended over Singapore at the time. Thus Hang Tuah is taken into the Bendahara's service. The discovery of Hang Tuah's talent as a warrior is a foreshadowing of a bright and excellent future ahead.

The epic also narrates that although Melaka grew into a great kingdom, the King of Melaka enjoyed going to Singapore for rest and recreation. On one of his visits, the royal crown fell into the Straits of Singapore and when Hang Tuah dove in to retrieve it, his kris was swallowed by a white crocodile. 
Thus both the King's crown and Hang Tuah's kris were lost and could not be saved. This interesting event is also of great symbolic significance, foreshadowing the fall of a Malay kingdom (the symbol of which is the crown) and of Malay valour (symbolized by Hang Tuah's kris) at the hands of Western powers-the Portuguese (represented by the white crocodile).

The author of Hikayat Hang Tuah chose the Singapore Straits as the setting that witness and prefigures two important points in history, that is, of the rise and fall in Hang Tuah's life as a Malay warrior, and it also foreshadows the rise and fall in the history of the Melaka sultanate, or the glory of the classical Malay sultanate.

\section{Singapore as the Centre of Malay-Hindu Literature (Translation and Rewritng)}

Singapore's inimitability is reflected not only in the two great works of classical Malay literature mentioned.During the era of the Malay sultanates in the 13th and 14th centuries CE, Singapore was the centre for translating and rewriting Hindu texts into Malay. Teuku Iskandar $(1995)^{3}$ has explained this at length.

\section{STAGE 2 -ROAR OF THE BRITISH EMPIRE AND THE HISTORY OF PUBLISHING (1819-1900)}

Malay literature entered a period of great change during the British colonial era in the Malay world. Printing technology changed Malay literature from the form of handwritten manuscripts to the printed form (block printing, lithography and letterpress printing). The printing press, which offered a new channel or vehicle for Malay letters, was introduced in Melaka in 1817 through the efforts of Father William Milne of the London Missionaries Society (LMS) who brought a printing press from Bengal, India in 1816. Abdullah Munshi was the first Malay to learn the craft of printing at the age of about 20. The efforts of Abdullah, who assisted Reverend Claudius Thomsen in publishing, were established with the publication of the first Malay magazine, Bustan Arifin in 1821-1822.

Abdullah arrived in Singapore with C. Thomsen four months after Singapore permitted the British East India Company to set up a trading post on the island in 1819. Although Abdullah was born in Melaka and learnt the craft of printing there, he was evidently a very creative and prolific writer 
while he was working and living in Singapore. Most of his classics which are major contributions to the development of Nusantara literature were produced in Singapore. Stamford Raffles, with the help of William Farquhar, planned and developed Singapore. One of Raffles'efforts included the division of land for various development projects. With Abdullah's help and his language and publication skills, he published a Proclamation concerning this division of land on 2 December 1822. The publication of this Proclamation is a major historical event because it is the first publication produced in Singapore.

Abdullah's contributions as a chronicler of Singapore's history during the time of Raffles up tol the time that it became a trading city is also important, and this is reflected in Hikayat Abdullah (The Tales of Abdullah), a work that can be considered as a comparison between the rule of Malay monarchy and British administration. Kisah Pelayaran Abdullah (The Story of Abdullah's Voyages), is a work on how civil war in Kelantan affected trade in Singapore, and Kisah Pelayaran Abdullah ke Judah (Abdullah's Voyage to Jeddah) offers a short depiction of Singapore as the hub for haj pilgrims in the region. His poems such as "Singapura Terbakar" (Singapore in Flames) and "Kampung Gelam Terbakar" (Kampung Gelam in Flames) depict the danger the residents of Singapore are in because of inept of fire-fighting systems. Meanwhile, "Cerita Kapal Asap" (Story of the Steam Ship) speaks of the introduction of Western technology in Singapore. Abdullah also translated and worked on the publication of early Malay-language school text books such as Ilmu Bintang (Astronomy)(1840), Hikayat Dunia (The Story of Geography)(1843), Hikayat Eropah (European History)(1843), Hikayat Kapal Asap (The Story of Steamships)(1843) and Hikayat Binatang (The Story of Natural History) (1846). In terms of dictionaries, Abdullah, together with Thomsen, compiled and published a Malay Vocabulary in Melaka; a second edition was published by the Mission Press in 1827. According to John Bastin, this was "the first Malay dictionary or word-list printed in Singapore" (1983).

These are Abdullah Munshi's contributions to publishing in Singapore. He was the first person born in Nusantara to master printing technology and the information technology of his time to produce Malay-language books, using sophisticated techniques and printing technology. He also used his expertise to train a new generation of experts who subsequently produced important work in the development of printing and publishing in Southeast Asia. 


\section{The Centre for Islamic Publications and Printing in Southeast Asia $(1860-1920)^{4}$}

The printing activity pioneered byAbdullah in Singapore continued to progress in an exceptional manner after his death in 1854. If Abdullah was just an apprentice in the pioneering period, helping out in a European-owned printing and publishing house the subsequent period saw the emergence of the Malays/Muslim own publications after they had learnt the craft of printing from the West. Now they came into their own as entrepreneurs in the world of printing, competing with European and Baba Peranakan (or Straits-born Chinese) publishers. These three groups produced diverse books in Malay according to individual objectives, interests and literary tastes. For example, the Baba community produced translations from Hokkien to Baba Malay. Apart from introducing new types of literature associated with Chinese popular culture into Malay literature, they also had an appreciation for other well-known types of Malay literature such as pantun and syair. On the whole, the tendency for these publishers, whether Malay or non-Malay, who published books in Malay shows the role and function of the Malay language as the lingua franca of the plural society of Sinapore which was comprised of multi-ethnic societies and cultures.

The earliest Malay/Muslim publishers emerged in Singapore only in 1860, after the European publishers. From then until 1880, the publication of religious books in Malay in Singapore grew rapidly reaching its climax between 1880 and 1900. Although Islamic publishers emerged earlier in Palembang, Indonesia as early as 1848 , with a number of Javanese publications in the late 1850 s and early 1860 s, none of them could compete with the position of Singapore. Outside the Malay world, the publication of Islamic books began relatively late. Malay books were published in Bombay in 1874, and in Mekah only in 1884. This made Singapore the foremost publishing centre of the 19th century. As Proudfoot explains:

Singapore thus emerges early as the leading centre of Muslim publishing in SEA during the nineteenth century, as the first centre of Malay language Muslim printing anywhere in the world.

(Proudfoot, 1993:27)

Nevertheless, Singapore's position as abook production centre subsequently was threatened and experienced a period of decline from 19001920 owing to the competition of books imported from Bombay, Mekah, 
Cairo and Istanbul which in this period increasingly flooded the Southeast Asian markets, and their quality was considered better compared to locally published books.

However, Singapore's position as a centre of Malay intellectual activity was not affected because publishers, thinkers and leaders of Singapore chose to channel their attention and contribution to local newspapers and magazines which were beginning to find an audience and have an influence on local residents. This was the platform for the subsequent stage of literary development.

\section{STAGE 3-THE ROAR OF MODERNISM AND MALAY NATIONALISM(1900 - before 1945)}

In the early 20th century, there arose an awareness among a group Islamic intellectuals of Southeast Asia for the need to advance the thought and life of their community,so they could progress from their position which was backward and disadvantaged, compared to others who were more educated and enjoyed a better standard of living. These Islamic thinkers were influenced by the fervor of reform movements that emerged in the Middle East.The Muslim intelllectuals obtained an education and exposure to the thought and Islamic reform movements there, and after completing their studies returned home with the same drive to reassess the way of life and role of Islam among Malays/Muslims of Southeast Asia. At the same time, the education policies of the British and Dutch colonizers' and political developments in other colonies such as India and the Middle East stirred the spirit of awareness among the elite of the need to raise the standard of living of their communities and to push for independence from the grip of colonial powers. The spirit of reformation or modernization and nationalism were intensified by the effects of the war and the Japanese Occupation of Southeast Asia. Therefore nationalism was the main theme in Malay letters and the source of inspiration for Malay literary works of the time.

Among Malay writers with nationalist aspirations, the most important was Harun Aminurrashid, an educationist and literary figure, who was a product of Sultan Idris Training College, Tanjong Malim. He was a prolific Singaporean writer who produced hundreds of works in a variety of genres. As a productive historical novelist, Harun or "Pak Har", produced scores of works of historical and social bias aimed at raising the awareness and spirit of the Malay community by drawing on historical sources or elements. 
Among his well-known historical novels are Panglima Awang (Panglima Awang) (1958), Anak Panglima Awang (Son of Panglima Awang) (1961), Tun Mandak (Tun Mandak) (1963), Gugur di Lembah Kinabalu (The Fall at Kinabalu Valley) (1963), Wan Derus (Wan Derus) (1966) and Peristiwa Laksamana Cheng Ho ke Melaka (Admiral Cheng Ho's Journey to Melaka) (1969). Harun's contribution to the development of historical novels received international recognition with the award of The Certificate of Merit by the Board of Editors of the Dictionary of International Biography based in London. In 1968 he by the Board listed him among the most famous figures in the world. At the same time, Simpang Perinang (Perinang Junction) (1966) one of his novels on his community, themed on a multi-ethnic community,was selected by UNESCO for translation into English and Urdu.

From 1876 to 1941, there were 147 Malay-language newspapers and magazines published in the Malay States and Straits Settlements. Most of these (68) were centred in Singapore and Penang (36). The first Malay-language newspaper produced and published in Singapore was Jawi Peranakan in 1876 , a weekly newspaper which was also the longest-lasting among pre-war publications prior to 1941, that is, 19 years(1876-1895). The publication was started by the local Indian-Muslims(also known as Jawi Peranakan) who considered themselves Malay and concerned themselves with affairs of the Malay community. At this early stage, the Baba Peranakan or Straits Chinese also published The Straits Chinese Herald (1891) with a column in Malay, and the Bintang Timor (1894), which was published entirely in the Baba Malay dialect. In 1906, the monthly magazine Al-Imam was published, with Sheikh Mohd Tahir Jalaluddin as Editor. He was succeeded by Hj. Abbas b. Mohd Taha. Al-Imam, considered the first Islamic reform magazine in Southeast Asia, was influenced by Al-Manar magazine in Cairo. Al-Imam lasted till early 1909, after which the bi-weekly Neraca appeared, from 1911 to 1915. This was followed by Tunas Melayu (1913) and Majallah Al-Islam (1914-15).

The second period of Malay journalism occurred between 1906 and 1916, when influential national dailies and reform magazines appeared. Utusan Melayu was launched in Singapore in November 1907 with Mohamad Eunos Abdullah as first Editor-in-Chief. Mohamad Eunos is considered the "Father of Malay Journalism". This newspaper, which was published three times a week, later became a daily and the only Malay newspaper at the time with a wide circulation of faithful readers on the Peninsula as well as in the Straits Settlements. In fact, it was not a translated newspaper but a 
Malay edition of the Singapore Free Press newspaper published which was active until 1918. At the beginning, Utusan Melayu was published in the Jawi script but its main story and the Editor's column were in romanized script.This was followed by another daily, Lembaga Melayu in 1914, also edited by Mohamad Eunos.

The second period of development of newspapers and journalism is important for the emergence of newspapers that were entirely in the Malay language. However at the time, Malay newspapers and journalism were still closely bound by English newspapers, because although they were not translations, they were still Malay editions of English newspapers. These newspapers were not accepted by the community as the true voice of the Malay people since they were run by those who were close to the British authorities and dependent on funding from non-Malay groups, such as Arab tycoons. This tendency made Malay scholars and thinkers persevere in their efforts to establish a newspaper that would truly be the voice of the Malay community, and funded by its own community.

The dream to publish a newspaper that would represent the "Malay voice" began when Onn bin Jaafar, considered as part of a new generation of thinkers, became the first Editor of Warta Malaya (1930-1941), a daily based in Singapore. This newspaper, led by other editors, became an important mouthpiece for the Malay community until this position was taken over by Utusan Melayu, which reappeared in 1939. This time, Utusan Melayu was the outcome of efforts of the Malay Union of Singapore (KMS), a social quasipolitical association established in Singapore by a group of public figures like Yusof Ishak and Embok Soloh, both of whom actively campaigned for special funds for the establishment of a Malay-owned newspaper without help from other communities. This noble effort of the KMS who wished to see Malays being independent succeeding in amassing huge donations from the public, including taxi drivers, hawkers and farmers from the East Coast of the Malay Peninsula. This newspaper was led by Abdul Rahim Kajai as editor. He was an authorititative journalist and literary figure who was able to turn this newspaper into a voice and mouthpiece of the Malay community, which was run entirely by the Malays.

\section{Syonan - Rays of the Southern Sun and Growth of New Malay Poetry}

During the Japanese Occupation, the clarion call of theslogan, "Asia for Asians" and "Greater East Asia Co-Prosperity Sphere" brought to an end all 
expression of admiration of western power. The period of Japanese Occupation was very brief, about three and a half years, yet it left a tremendous impact on Malay thought and literature. Firstly, the Japanese united the regions of Sumatra and Malaya under a single administration based in Singapore. Many writers from Sumatra worked in Singapore as editors of a number of newspapers and magazines, such as the daily, Berita Malai (established with the amalgamation of Warta Malaya and Utusan Melayu). Though freedom of the press was curbed by the Japanese, their relationship with Indonesian writers was cordial and this had an effect on the pattern and development of the language and the literature it produced.

In terms of language, there was a strong awareness of the role of language, as far as nationalism and political aspirations were concerned. The hope of becoming a united people had arisen even before the Japanese arrived, and their presence intensified the spirit of nationalism. Literary works, whether in the form of poems, short stories, radio or stage dramas, were mainly aimed at making the community aware of a new responsibility and emphasising the importance of the spirit of struggle. It is interesting that the elements of melancholy, tone of despair and the tendency to deliberate on the issue of poverty and social backwardness in Malay literature of the early 20th century were eclipsed by works of a patriotic tenor, with the aim of planting seeds of struggle in life. For example, Masuri SN wrote poems themed on struggle, such as "Bunga Sakura" (Sakura Flower) and "Rosku Puja" (My Beloved Rose). His, and that of several other poets who pioneered the poetry during the Japanese Occupation represent a new stage in the development of modern Malay poetry.

\section{STAGE 4 -THE ROAR OF INDEPENDENCE AND THE VOICE OF THE PEOPLE (1945-1957)}

After World War II, Singapore continued to held centre stage in Malay letters and culture. This was because Singapore had a complete infrastructure for such activities. Ever since it was established, Singapore had been a city of port, trade, British administrative and military base, and centre for publishing, printing or information. In terms of education, it was also a centre of learning because teacher training colleges and institutions of higher education began in Singapore. For example, the first Malay Teacher Training College in Teluk Blangah, established from 1878 to 1895; the University of Malaya set up in 1949, and Nanyang University in 1955. In fact, the Department of Malay Studies at University of Malaya, Singapore established in 1953 was very 
important to the study of language and literature which eventually influenced the quality of works produced by university graduates who were scholars and writers. All the advantages of infrastructure facilitated Singapore's role as a cosmopolitan centre of culture, the film industry, the staging of traditional Malay bangsawan and theatre performances, and Malay art form of music. In addition it continued to be the pulse of Malay letters and journalism till the mid-20th century.

Developments in politics, education, economy, society and culture, and Malay journalism are not only important to the understanding of the development of the thought and awareness of social and political aspirations of the Malay community, but also factors that had a great impact on the production of the new culture and literature. Writers fine-tuned and experimented according to developments in surroundings and new spirit of life. In fact, these factors shaped forms of communication, representing a model for their writing and inspiration for their art.

At this stage, new western forms of writing such as sajak (free verse poems) and short stories and the like became the model for new writers. These new forms began to be explored in addition to the traditional story-telling and Malay poetic forms such as pantun and syair which were preserved and continued to be popular. Newspapers and magazines became new vehicles for presenting creative works, through new forms of expression such as serial novels, essays, and the beginnings of literary criticism. Elements of journalism, with an emphasis on issues, current events, and elements of realism rather than myth and legend, became important features of this new type of literature. On the whole, Malay literature underwent an evolutionary process that developed slowly in moderation, combining innovation and creativity with convention and tradition. Literature became the conscious channel of choice for writers to discuss issues and social problems, and utilized as a service to society.

\section{ASAS' 50 and Social Aspirations}

Perhaps the most interesting phenomenon in Malay literature after World War II was the establishment of Angkatan Sasterawan 50, better-known known as ASAS ' 50 . ASAS' 50 was set up by 19 young Singaporeans on 6 August, 1950 and founded on their call and aspiration to effect major reform in society using literature as the medium. These young writers aspired to break down inherent obstacles that hindered progress, justice and social well-being in their 
society. The objective of ASAS' 50 was to free the Malay mind of old beliefs, constraints that restricted their soul and freedom of thought, feudal attitudes, outdated teachings and superstition. The emergence of ASAS' 50 reflected the idealism and dynamism which were important to Malay literature in the mid-20th century. ASAS' 50 , established in and operating from Singapore, left its mark on the history of Malay literature. It was a noble aspiration for the people and the outstanding artistic spirit for their art was reflected in their motto "Art for Society".

\section{STAGE 5 -ROAR OF A DREAM FOR A NEW UNITED LAND (1957-1965)}

The period 1957-1965 was critical to the history of both nations. The history of Malay literature is a history of the Malay struggle in facing currents of progress and independence. Literature was the record and reflection of the awareness, spirit and process of struggle of the community for a better life. Their hopes and aspirations to be free of the threat of colonization had been immortalized ever since the glory days of classical literature, before the World War and Japanese Occupation, to the time of ASAS'50. The founding of an independent nation is the greatest dream of every colonized race and land. This dream was achieved when Malaya obtained independence on 31 August 1957. Singapore too obtained self-government from the British in 1959 and subsequently joined Malaysia in 1963 in the hope that it would be a part of one large and sovereign nation.

\section{Interest from Non-Malays and Contribution of Nanyang University, Singapore}

It was an interesting decade in the development of language and literature, promising a higher, wider and grander status and role for the Malay language not only in Malaysia but also in Singapore. There was greater interest in Malay language and literature among non-Malays in Singapore at this stage. This is evidenced by the language courses, Malay1 dan Malay 2, begun in March 1958, and it was taught by Rashid Manan, the Indonesian Consul to Singapore and Malaysia. From October 1958 it was taught by Dr Li Chuan Siu. Many non-Malay students took the course since the Malay language had been chosen as the national language of Malaysia and Singapore (Li Chuan Siu, 1967:190). NANTAH (the alumni of Nanyang University) produced a total of 12 issues of the magazine, Ikatan Mahasiswa Universiti Nanyang 
from December 1958 till the end of 1963. The magazine included poems, short stories and student activities. Yang Quee, Liaw Yock Fang, Tan Chin Kwang, Goh Choo Keng, Chan Maw Woh and Tan Ta Sen were NANTAH graduates who made frequent contributions. There were also a number of Malay teachers who were enrolled as postgraduate students at Nanyang University in the 1970s, like Suratman Markasan, Fatimah Mohd Noor and Juri Wari.

\section{A Song of Hope for Singapore's Growth}

Hopes for a united Singapore and Malaysia were also recorded in the song, Singapura Waktu Malam (Singapore by Night). It was sung by Saloma, in Labu Labi the 1962 film classic directed by P. Ramlee in 1962. ${ }^{5}$ The song was composed by P. Ramlee and lyrics were by S. Sudarmaji. The lyrics reveal political aspirations expressed in an artistic medium which was popular at the time:

\section{Singapura maju jaya \\ tetap dalam aman dan sentosa \\ makin hari makin kaya \\ apabila di dalam Malaysia.}

(Singapore, progressive and flourishing

peace and harmony within

day by day prospering

as part of Malaysia thriving.)

Singapore was to grow as a peaceful, tranquil and prosperous part of Malaysia. Such were the great expectations recorded in this melodious traditional Malay keroncong song. Obviously this dream was fulfilled when Singapore joined Malaysia in 1963.

\section{A Song of Love and Shared Dreams for the New Malaysia}

With this dream fulfilled, a mood of joy and happiness arose when Malaysia was formed as a new nation, with Singapore as a part of a large "new family". The joy and happiness celebrating the love and pride of the people of a new political family was recorded in the song Malaysia Baru in the film Kasih Tanpa Sayang directed by Omar Rojik in 1963, that is, when Singapore became part of the new Malaysia. The song, composed by Kassim Masdor 
with lyrics by Omar Rojik, was sung by Aziz Jaafar. It was later re-recorded by M. Bakri to the musical accompaniment of The Antarctics in $1965 .{ }^{6}$ The lyrics are as follows:

\section{Malaysia Baru}

Cinta bangsa rasa mulia

Cinta wanita rasa bahagia

Menjadi kita penuh daya

mencipta hidup sempurna.

Oleh itu mari kawanku

berpimpin tangan berganding bahu

Segera capai cita yang satu

di alam Malaysia baru.

\section{(The New Malaysia}

Love for the nation brings us pride

Love for a woman brings delight

It make us allso energized

To create perfection in our lives.

Therefore come, come my friend

Shoulder to shoulder hand in hand

Let's quickly attain the dream we've shared

In the new world of Malaysia we stand.)

However, history shows that the tone of joy in the song ofthe Singaporean artistes for the "dream we've shared / for the new Malaysia here we stand", a Malaysia which Singapore was part of, was to be only briefly enjoyed, that is, from 1963 to 1965. This was because hopes of building language, literature, harmony and economy, and a life together in happiness, came abruptly to an end as Singapore was made to leave Malaysia when the Parliament of Malaysia voted for the expulsion of Singapore. This was the point of divide between the two nations that had all along been united by history and culture. 


\section{THE LAMENT OF SEPARATION, 9 AUGUST 1965}

Separation and independence greatly affected the community and literature of Malays in Singapore. All of a sudden the Malays on the island found themselves a minority in their own homeland, cut off from the refuge of the original ocean of Malay culture and history under whose protection it had been all along. The essential bonds of tranquility and security when they used to be part of a larger Malay family were destroyed, and now the Malays of Singapore were worried about limitations in the new nation.

The joy had been temporary, transformed in a trice to sadness and loss. This is visible in Sumbangsih (Contribution) a stage play by Rawan Hiba or Rahman B., Haji Othman bin Haji Abdullah's nom de plume. Haji Othman produced the play a few months after the political split. The performance was directed by Bani Buang with Rawan Hibaas the main actor, and organized by the Singapore Arts Group (Perkumpulan Seni Singapura).

The play is about Yahya and Sapura, a pair of lovers torn apart because Yahya is poor, and one of his legs has been amputated. From the storyline and dialogue it is clear that the two characters symbolize the relationship between Malaysia and Singapore. In addition, the sadness of the lovers' separation is clearly expressed in the lyrics of the play's theme song:

Kini semua hancur dan musnah

Niat bercantum badan berpisah

Kembang mawar beri padamu

Lambang kita pasti bersatu

(Now all is devastated

hearts together bodies separated

to you I give this rose, a sign

we will be united one day in time

Oh sumbangsih hati ke hati

Nada rindu luhur sejati

Kami insan rindu percantuman

Kami rindukan keadilan

$\mathrm{O}$ one heart to another giving

A voice of true lament and yearning

For unity we are pining

For justice we are longing.) 


\section{TRACING THE LIMITS OF THE SKY OVER ONE WORLD}

\section{Uncovering Symbols of Separation of Two Nations}

Singapore's separation from Malaysia was the theme of many Singaporean works. In fact many creative works were produced, either in the form of poetry, song, drama, short story or novel for which this historical event was the choice. However, so far there have not been efforts to collect and study these works despite their undisputed value in discovering the nationalistic spirit and awareness of the multi-cultural people of Singapore since its independence. The article selects only three works that touch directly on the event. They are by three Singaporean writers from different backgrounds or generations. These are Mengesan Jejak Pelayaran Munshi Abdullah by Harun Aminurrashid (1966); Batas Langit by Mohd Latiff Mohd (1996) and Satu Bumi by Isa Kamari (1998).

\section{Fall of the Buds of Life}

Harun Aminurrashid is a nasionalistic writer who expresses love and pride for Singapore. He is aware of the connection of Singapore with the rest of the Malay World and hopes Singapore will continue to carve a niche for itself in the world for its achievements. Harun feels deeply a Malay for the Motherland. He is represents the early generation of Singaporeans who had a love for the common Malay Land. It is this larger Malay Land with a glorious history that he champions in a majority of his works. Therefore he was deeply moved when Singapore was separated from Malaysia.The Malay Motherland or Malaya was analogous to the coconut that grows abundantly all over the Malay World as a tree of great value in the life and culture of the Malays.While in Kampung Daling Besar, Kuantan, his grief over the political separation is likened to "the falling of coconut buds":

Fikiran saya melayang jauh, kadang2 menjadi tanda-tanya kapada otak saya, berapa ramai agak-nya manusia yg ta'dapat tidor macham saya di-ganggu oleh fikiran di-sebabkan 9 ogos itu? Saya ....Sedang saya mengelamun... tiba2 saya terkejut mendengar bunyi berdebok tidak jauh dari tempat saya berdiri di-tepi tingkap itu. Saya memerhatikan di-chelah2 pokok kelapa itu kalau2 ada orang berjalan...Rupanya tupai yang melompat. Benda yang berdebok itu juga rupanya mumbang kelapa gugur bekas di-makan tupai.... 
Kata hati saya, "Rupanya ada juga kawan yang ta'tidor, tetapi sayang tupai itu ta'dapat di-ajak berbual atau bertukar2 fikiran. "....Kata hati saya kepada tupai yang jatoh, "Sa-pandai2 tupai melompat, ta'sa-kali2 jatoh juga!"

My thoughts wandered far, at times there were questions in my mind, I wondered, how many like me could not sleep, disturbed by such thoughts of 9 August? I ... was day-dreaming like this ... suddenly I was startled by a loud thump from beside the window, not far from where I stood. I peered between the coconut trees, perhaps someone was walking there ... it turned out to be a squirrel bounding away.The sound of the thump was from a stalk of coconut buds that had fallen, for the squirrel had chewed it ...

In my heart I said, "It looks like I have a friend who can't sleep either, but pity, I can't engage the squirrel in talk or exchange ideas..." My heart said to the squirrel, "No matter how good you may be at jumping, once in a while even you will fall!"

(1966:179-181).

Harun's writings are quite interesting because apart from recording his personal thoughts on the event, it also records the general reaction of the public at the unexpected news.

Saya duduk di-kedai2 kopi....Kesimpulan perbinchangan mereka kerana ta' puas hati mendengar berita yang mengejutkan itu dan sa-olah2 mengambil keputusan, "Mengapa jadi begitu!"

Sitting at roadside coffee shops ... The gist of their conversations was about dissatisfaction at the shocking news, as if they were asking, "Why has it come to this?!"

\section{$(1966: 140)$}

Kejadian besar di-bumi kita telah berlaku dalam masa .....masa hampir sa-minggu sa-lepas terjadi peristiwa 9 ogos itu, keadaan fikiran terganggu dan merasa seperti "kosong" kerana di-penuhi oleh tanda-tanya, terutama orang Melayu S'pura yang seramai kira2 250,000 orang lebih itu, dengan tiba2 tidak lagi menjadi rakyat Malaysia, sekarang menjadi rakyat S'pura yang merdeka, mesti menyingsing lengan baju untuk berjuang dalam hidup bersama dengan saudara-saudaranya rakyat yang bukan Melayu, yang mempunyai taraf sama sebagai rakyat S'pura.

This big event in our world occurred ... about a week after the 9 August event, at a time when people were disturbed and simply "went blank" because 
their minds were full of questions, especially Singapore Malays, numbering about 250,000, who were suddenly no longer Malaysians, who were now free Singaporeans, and who had to roll up their sleeves along with their fellow non-Malay citizens with the same rights as themselves, as Singaporeans.

(1966:206).

\section{MUHAMMAD LATIF MOHAMMAD'S BATAS LANGIT(1996)}

Batas Langit portrays the social problems and poverty of people from various ethnic groups living in a kampung in Geylang Road in Singapore at the time of Independence from British colonial rule and the separation from Malaysia. The story is from the point of view of Adi, a youth from a poor family who faces all sorts of problems. His father is a gambler who neglects his family and eventually dies of diabetes. Adi is very dependent on his mother. However, he is intelligent and independent and capable of earning a living to help his mother. He also has a strong resolve to study, and encouraged by his neighbour, Abang Dolah. Adi is still a student in a Malay secondary school and loves Malay literature. He often observes the advice and opinions of Abang Dolah who has a strong influence on him. While Singapore and Malaysia are still one, Adi hopes that his Malay education can guarantee his future.

\section{The Banyan Tree, Protector of the Soul}

Adi often climbs up a banyan tree to play there. Adi'slife, and that of other villagers are skillfully portrayed, with the banyan tree symbolising a witness and keeperof the secrets of their suffering, resulting from political unrest in the land, and also as a symbol of the life and political entity of Malaysia:

Kata orang, pokokjejawi ini telah berusia ratusan tahun. Pokok ini kononnya berpenunggu dan orang takut lalu di bawahnya pada waktu senja atau waktu malam. Daun jejawi yang lebar-lebar dengan dahannya yang sebesar pemeluk, seolah memayungi rumah atap di bawahnya dengan amat gagah. Batang pokok jejawi ini, terdiri daripada akar-akar pokok sebesar lengan manusia, batangnya kelihatan telah bercalar-calar bekas ditoreh....

(People say this banyan tree is hundreds of years old. It's supposedly occupied by spirits and people are afraid to walk under it at twilight or at night. These big, broad leaves and its branches as thick as a human body are like a mighty protector of the attap-roofed huts beneath it. The trunk of 
this banyan tree is made up of many roots, each as big as a human arm, and etched with deep gashes...)

Adi terpaksa berpisah dengan pokok jejawi yang amat disayanginya. Pokok jejawi depan rumah telah menjadi sahabat Adi semenjak dia belum tahu membaca lagi. Akar dan dahan jejawi sudah kenal betul dengan bau badan Adi. Mengkarung di atas pokok sudah kenal akan Adi. Jiran-jiran terpaksa Adi tinggalkan. Adi sudah membayangkan kesedihan yang bakal dirasainya apabila berpindah nanti.

(Adi was forced to be separated from the banyan tree he loved deeply. This banyan tree in front of the house had been Adi's friend since even before he learnt to read. The roots and branches of the banyan were only too familiar with his smell. The chameleons on the tree were familiar with Adi. Adi had to leave the neighbours too. He could already feel the grief that would descend on him with his departure )

...Adi merasa sangat pilu apabila lori hendak bergerak. Adi merenung pokok jejawi lama-lama. Adi merenung rumahnya dengan air mata berlinangan. Semalam Adi panjat pokok jejawi. Bekas torehan Adi di dahan pokok jejawi perkataan:MALAYSIA, masih jelas. Adi macam hendak peluk pokok jejawi, apakan daya badan pokok jejawi terlalu besar untuknya.

(Adi felt a deep sorrow when the lorry began to move. Adi gazed at the banyan tree for a long, long time. Adi gazed at his house with tears in his eyes.The night before Adi had climbed up the banyan tree. The word MALAYSIA which he had carved on the tree was still visible. Adi felt like hugging the banyan tree but how could he; the body of the tree was much too big for him )

$(1996: 127)$

\section{ISA KAMARI'S SATU BUMI (1998)}

Isa Kamari's novel Satu Bumi is about the meeting between Irman, a young engineer and Yassir, an old man who is a grave-digger at Bidadari Mosque in Singapore. The cemetery at the Bidadari Mosque, along with the grave of Irman's grandmother Swee Mei, are threatened because it has to be moved 
to another cemetery to make way for a development project. At the meeting, Irman tells Yasser the story of the late Swee Mei, his Chinese grandmother. During the Japanese Occupation, her family left his grandmother who was 18 with the family of Pak Durhakim, who is Riau Malay, because they were afraid she would be raped and tortured by Japanese soldiers. To avoid suspicion of the Japanese, Swee Mei was called Aminah and became their new relative, and subsequently married off to Malek, Pak Durhakim's nephew, that is, Irman's grandfather. Yassir also tells of the struggles in his life in the political arena which is full of twists and turns. The stories of Aminah and Yassir are presented by turns and in parallel throughout the novel. It is interesting that the characters in the novel are linked symbolically and philosophically with the history of struggle and political upheaval in Singapore in its struggle for independence.

\section{Separation of Mother and Child -A Shattered Mirror of Grief}

The second story is about Aminah, who is newly-converted to Islam, and life with her foster family, the family of Pak Durhakim. It's a peaceful life even during the time of the Japanese Occupation. Aminah gives birth to a son named Ilham, and even though she works as a samsui-woman at the Hababot (port) of Singapore, she holds steadfast to her faith in Islam. Differences in colour of skin or race are no issue in this unusual family. Interestingly, the bond of love in the family is likened to the union of Nusa Selatan (Singapore) and Nusa Secita (Malaysia). However, the joy of political union does not last long due to political conflict.

Like Nusa Secita, the safety and happiness of Aminah's family and that of Pak Durhakim are threatened by the ethnic tensions that result. In a procession to mark the birthday of Prophet Muhammad, a riot breaks out and Pak Durhakim is killed. Aminah dies after being brutally gang-raped by a group of enraged Chinese youths who feel insulted when they learn that she is a Muslim convert. This leaves her son, Ilham, alone and grieving.

The grief of a child whose mother has died is portrayed in the same way as the people's grief when Nusa Selatan is separated from Nusa Secita:

Ibu dan datuk tidak bersamanya ketika Perdana Menteri mengisytiharkan kelontaran Nusa Selatan dari Nusa Secita setahun kemudiannya. Perdana Menteri menangis ketika itu. Ilham tidak tahu mana satu yang lebih menyedihkan. Air matanya telah kering kerana anak telah terpisah dari ibu. Terputuslah tembuni yang menalikan ikatan kasih, siasah dam sejarah. Selat Tebrau bergelora sentiasa. 9 Ogos adalah kaca duka dan retak cermin jiwanya. 
(His mother and grandfather were not with him when the Prime Minister announced the separation of Nusa Selatan from Nusa Secita a year later. The Prime Minister wept at the time. Ilham did not know which was more sorrowful. His eyes had become dry since separation from his mother. The cord that had bound love, politics and history had been torn. The Tebrau Straits would be forever choppy. 9 August, 1965 was the mirror of grief and the mirror of his soul hadshattered).

(1998:160).

\section{Imagery and Symbolism of Separation}

On the whole, the separation of Singapore and Malaysia was a great and unexpected historical tremor that caused complex and varied reactions at all levels of society in both countries, particularly among Malays in Singapore. Although writers like Harun Aminurrashid of the older, mature generation were sad and disappointed that the dream to live within the vast Malay world was destroyed, they were compelled to accept the fact of history calmly. Although the Singaporean Malays were concerned that they were now a minority and still backward, he was optimistic and hoped that Malays would take the opportunity to learn from the success of the other ethnic groups and grow to become a symbol of progress of Malays as a whole. Whereas second-generation writers educated in Malay, like Mohd Latiff Mohamad, who were trapped by the political upheaval prior to the separation, were not only shocked and saddened but also disillusioned and cynical at being cheated and victimized by the political playoffs. They were extremely disappointed that their future was ruined because a Malay education was no guarantee of their future.

However, the post-1965 generation of writers like Isa Kamari, who were educated in English and qualified by the system of education and life of the new nation, enjoyed a more stable economic and political climate, and were better equipped to accept the historical fact. In fact even though this generation was aware of their history, and wished to uncover the secrets of the history, they did not carry the emotional burden of the previous generation of Malays. They not were only accepting of the march of history but also awed by the daring and honest efforts of their leaders. Interestingly, the educated Malays of post-1965 Singapore were confident of Islam as a stronger bridge for social and national unity than pride of race and ethnicity.

This is the roar of the lion in pain, forced out of the jungles of the Malay Land. 


\section{POST-1965 LITERARY DEVELOPMENT - THE ROAR OF LITERATURE IN THE JUNGLE OF LION CITY}

What was the situation in the literary life in general after the historic event of 1965? Literary development in Singapore from post-1965 till the present time can be divided into three phases. The classification is generally based on the patterns of thought or psychological perspective of writers reflected in works and not on chronology or age of writers. It should be noted that writers like Suratman, MAS, Mohd Latiff Mohd and Isa Kamari have been writing throughout, that is, before or after these phases. The following are three post-1965 literary phases:

1. Phase of Loss (1965-1980)

2. Phase of Searching(1980-2000)

3. Phase of Restoration (2000to the present)

\section{Phase of Loss (1965-1980)}

The period between 1965 and 1980 was a crucial orcritical phase in the Malay community and literature in Singapore. This was a period of upheaval because as a result of the political separation there was a sense of loss and marginalization because the status of the Malays as a race was suddenly altered.The Malays were sad, frustrated, angry and hurt by the separation because they felt rejected and politically marginalized (Shaharudin Maaruf and Sh. Maznah S. Omar, 2000, 2000:113). Their psychological state was exacerbated by the rapid development or urbanization process which made them feel "uprooted from the traditions of life", as they were moved from their traditional homes in the kampung to flats. Important writers of the period are Muhd Arif Ahmad (MAS), Masuri SN, Suratman Markasan, Noor S.I. and A.Ghani Hamid. Their works were the community's main voices of loss at the time. Fuad Salim's short story "Ke Mana Hati Hendak Kubawa" (Where Shall I Take My Heart) (1973) and Suratman Markasan's short story/ novella "Penghulu Yang Hilang Segala-galanya" (The Headman Who Lost Everything) (1998) are examples. The voice of loss can also be evinced from Suratman Markasan's poem, "Jalan Permulaan" (Setting off on the Road). The veteran writer also lead the ASAS ' 50 movement from 1977-1986, and from 1992-1994. The following is an excerpt fromSuratman's poem: 
Laut tempatku menangkap ikan

Bukit tempatku mencari rambutan

sudah menghutan dilanda batu-bata

Pak Lasim tak biasa lagi jadi penghulu

pulaunya sudah dicabut dari peta kepalanya

anak buah sudah terdampar

di batu-bata dan pasir-masir hangat.

Aku kehilangan lautku

aku kehilangan bukitku

aku kehilangan diriku.

(The sea where I caught fish

the hills where I gathered rambutans

have turned to jungles of concrete

Pak Lasim is no longer the headman

his island torn from the map of his mind

his followers stranded

on scorching pebble-stones and shore-sands.

I have lost my sea

I have lost my hills

I have lost myself.)

(Dewan Sastera, February 1981)

\section{Tone of Pessimism in Literary Works}

As a consequence of profound sadness and loss, the voice or tone of authors in this phase was evidently pessimistic, and lacking in conviction that life could get better for the community. This is quite obvious in a majority of literary genres including the poem, short story and novel.

A number of Singaporean literary scholars like Mohd Naim Daipi (1981), Masuri SN (1983), Rasiah Halil (1984), Hadijah Rahmat (1987, 1991), Sharifah Maznah Syed Omar (1992), and Shaharudin Maaruf and Sh. Maznah S.Omar (2000) noticed and discussed the indications of pessimism. It stirred sympathy in Masuri SN who, in his poems and essays, advised Singaporean writers not be mired by history but to be more positive and look forward to the future. Masuri expressed a positive point of view and attitude himself. He portrayed problems and challenges in life from a constructive 
and positive perspective. In fact, Masuri strongly resists pessimism in life, especially in the voice and expression of authors who appear to lose hope easily in the face of challenge and merely complain, reducing literature to a "house of sighs".

\author{
Kita tidak bakal balik \\ Menjadi perindu yang terus sendu \\ Sambil merintih keluhan pedih \\ Kita tidak bakal meneruskan \\ Gelisah pecah menjadi penghambat \\ (We will not go back \\ to lament and endlessly grieve \\ With moans and solemn sighs \\ We will not continue \\ With anxiety and fracture inhibiting us)
}

(“Kita Tidak Bakal Balik”, Mimpi Panjang Seorang Penyair, 1995:143)

The bitter experience of separation forced the Malays of Singapore to re-evaluate the way of life they had practiced all this time, and seek new perspectives and directions in a new political ecology. The Malays had to rise again to face changes in the system of a new life and try to find a way to improve their educational and economic achievements. This was the new focus and spirit in the phase that followed.

\title{
2. Phase of Searching (1980-2000)
}

Only after more than 15 years did Malay literature in Singapore finally see a transition to new thought in facing challenges from a perspective of Singaporeans within Nusantara. It was a stage of awareness and searching, as the community and writers of Singapore compared themselves to brothers and sisters of their race in neighbouring countries, to find continuity between elements of nationality, and culture or ethnicity.This is apparent in Mohd Latiff Mohammad's poem, "Melayuku Melayumu" (My Malayness, Your Malayness): ${ }^{7}$

\section{Melayuku Melayumu \\ Telah kutafsirkan makna Melayuku \\ Dari mata dan bibir sejarah}


Yang luka bagai selendang berdarah

Yang pilu bagai perawan berduka

...

Melayumu adalah bulan purnama

harum cempaka wangi cendana

Melayuku adalah pelamin yang patah

pusara yang legam

dan malam yang pasrah

\section{(My Malayness, Your Malayness}

I've interpreted what Malayness means

From the eyes and lips of a history

That's like a tattered shawl that bleeds

That's like a mournful maiden

Your Malayness is the full moon

the fragrance of frangipani and sandalwood

My Malayness is a broken bridal dais

a dark gloomy grave

and a surrendering night)

(Dewan Sastera, March 1983)

Apart from comparison with nearby neighbours, the process of searching also occurred by viewing the position of Malays at the international level, using international achievements and universal Islamic values as yardsticks. This is reflected in Hadijah Rahmat's poem, "Di Tengah Alam" (In the Centre of the World):

Bagaimana dan bila

manusia seperti aku dari bangsa kerdil

di Tengah negara kecil

akan lebih bererti dan disedari di peta dunia

dapat mengukir sebuah bekas di jalanan sejarah

menggantung sebutir kejora di dada cakerawala

sambil mengecap keredaan Allah! 
(How and when will this bel ittled race of people like me from a little country become meaningful on the world map inscribe its mark on the march of history pin star dust on the vast firmament and feel the delight of Allah's consent!)

(Berita Minggu, 8 May 1983)

The process of search and restoration of the culture and literature was quite a remarkable process that writers conducted in various ways, forming the focus of a great deal of the literature produced in Singapore.

\section{Phase of Restoration (2000 to the present)}

In the third phase one sees the voice of a new generation of Singaporean Malays educated in a post-1965 Singaporean system of education and enjoying equal progress with other ethnic and cultural groups of Singapore. This generation bears little or none of the "historical debt" of earlier generations.

This generation of writers exudes a confident voice of the new Malay to stand tall beside writers of other ethnic groups in Singapore and the rest of the Malay world. They display a concern for history, the fate of their people and sensitized to the challenging reality of life in Singapore. Among writers of this group are Rafaat Hamzah, Alfian Saat, Alin Mosbit and Hasnah Adam. The following poem, "Pasak Temasik" by Noor Hasnah Adam is possibly representative of the voice of this generation, expressing dualism and complexity of a new life in Singapore: ${ }^{8}$

\section{Pasak Temasik}

Biar beratustahun berlalu

Binatang itu tak pernah beradu

Pasak itu hanya membisu

Istana itu telah lama tak berlampu

Dan pulau ini masih dara berseти...

(Let hundreds of years pass

The animal never fights

The anchor is merely silent 
The palace lamps long unlit

And this island is still a maiden mislead ...)

\section{TheVision of a Literary Giant}

From the foregoing eight stages of development pre-and post-1965, one can see that the pulse of Malay literature is actively beating, even though it experienced several shocks at the phase of loss. Was Singaporean literature cut off from that of Malaysia or Nusantara? It appears that the prediction or vision of Usman Awang was correct and had become a reality! So far no separation has occurred in the literatures of the two nations. On the contrary, active efforts have been made to continue the connection between the literature of Singapore and that of Nusantara. Why and how is this so? Let us survey the measures resulting in this literary phenomenon.

\section{FIVE LITERARY LINKS BETWEEN THE LITERATURES OF SINGAPORE AND NUSANTARA}

\section{Links through Associations}

Literary, language, cultural and educational bodies in Singapore have an important part in continuing literary and social links with Malaysia and other countries of Nusantara. This is evident from the activities of ASAS' 50 in pioneering the Meeting of Nusantara Writers in 1977; the Kemuning Association of Singapore organized drama festivals involving three ASEAN countries in 1980, and a regional drama festival in 1982; The Malay Teachers' Union of Singapore (KGMS) organized a meeting of teachers from the region in 1985; and the Malay Journalists Asscociation of Singapore held the First Regional Journalists Meeting in 1988. Besides these initiatives, Singapore continues to be an important partner, participant and supporter of important regional literary activities frequently held since then till the present time (Hadijah Rahmat, 2002). To date, ASAS'50 andKGMS continue to maintain regional and bilateral literary links with institutions like GAPENA, Sultan Idris University of Education in Tanjong Malim (UPSI) and others. ${ }^{9}$

\section{Links through Publications}

Writers of Singapore like Masuri SN, Suratman Markasan, Isa Kamari, Rohani Din, Peter Augustine Goh, Hadijah Rahmat, Rasiah Halil, Djohar Buang 
and Munirah Jaafar, a young writer have published in Malaysia with DBP, university publishers or others.

Apart from individual works, Singaporean writers have taken the initiative to compile and publish regional writers' works in Malaysia. For example, Suratman has compiled Contemporary Short Stories of of Nusantara, and Rohani Din has published Bebas Melata Melantun Kasihan and Bebas Melata Mesra Serumpun, two compilations of poems by young writers from three countries.

\section{Links through Education}

Since Sang Nila Utama Secondary School was established in 1961, the first Malay school in Singapore, literature has been studied as a subject at the secondary and post-secondary levels. A majority of the literature texts used is by Malaysian authors: Kelapa Nan Sebatang, Angin dari Gunung, Lukisan Zaman, Seorang Tua di Kaki Gunung, Pulang Gadisku Pulang, Dekat Disayang Jauh Dikenang and Salina. ${ }^{10}$ Malaysian and Indonesian texts often become the main choice for analysis. Only a handful of local works have been included, among them Sarah Pengarang Kecil, Mail Mau Kahwin, Tiga Warna Bertemu and Subuh Hilang Senja.

Only as recently as 2013 has the Ministry of Education provided selected texts by Singaporean writers for Malay literature in secondary schools and at pre-university level (Tekad and Begitulah Kata-kata). ${ }^{11}$

Apart from links through texts, several secondary schools and junior colleges have special literature programmes (EMAS and MLEP), which have strengthened the connection through study visits to, and cooperation with Malaysia, Brunei and Indonesia. This includes activities by Kelompok Guru-guru Sastera which introduced the writer of the novel Restu to students in Malaysia and organized a visit to the island of Belitung, off Sumatra, for an appreciation of the novel Laskar Pelangi, and a poetry appreciation session in Bali.

At the level of higher education, the teaching of language and literature in universities (NTU, NUS \& UniSIM), is still centred on that of Nusantara, and in fact, only one of the courses offered is on Singaporean literature. Scholars from Nusantara like Dr Abdul Rahman Napiah (Mana Sikana), and Professor Budi Darma are employed by NIE and contribute through courses in introduction to Drama and Literary Criticism, including local Literary Theory. Other scholars like Emeritus Professor Dato' Dr. Asmah Haji Omar are invited to conduct intensive courses. 
At the same time, the Singapore National Institute of Education, NIE/NTU, NUS and UNiSIM are equally active in organizing language and literature activities involving scholars and writers at the regional and international levels like the international seminar on Masuri SN, and conferences on Malay language, literature and culture in general. At the same time, scholars of Malay studies in Singapore participate in events like seminars and publication of literary works, organized by Malaysia and other countries of Nusantara

\section{Links through Government}

Literary activities are organized among Malay-speaking and ASEAN countries with the involvement and support of the authorities. Involvement at the national level is supported by the government of Singapore, and this assists the process of literary connection. The ASEAN literature and SEA Write Award projects are instances. ${ }^{12}$ More recent activities are through the National Arts Council of Singapore (NAC) which organizes the annual Singaporean Writers' Festival and joint publication projects with writers of Singapore, Nusantara and ASEAN countries. A joint translation project between the NAC and the Institute of Translation and Books Malaysia (ITBM) is an example of such projects. The political shift in paradigms with regard to literature will animate and strengthen links of history, literature and culture of the Malays of Singapore and Malaysia and other nations of the Malay world. Other government institutions that are active and contribute to the development of the Malay language and literature are, the Singapore Malay Language Council (MBMS) which heads language and literature activities in the mother tongue at the national level, the Ministry of Education Month, particularly the Malay Language Learning and Promotion Committee (MLLPC) and the National Library Board (NLB). ${ }^{13}$

The most significant involvement and commitment from the Singapore authorities was the entry of Singapore into the Southeast Asian Literature Council (MASTERA) in October 2012. This was a bold and historic step towards strengthening connections between Malay literature in Singapore and the rest of Southeast Asia so that, God-Willing, it will be sustained and empowered.

\section{Links Through Roots in Classical Malay Literature}

Singaporean writers have not forgotten their roots in the shared culture of writers of the Malay world. Malay classics such as Sejarah Melayu, Hikayat Hang Tuah, Hikayat Abdullah and Malay folk tales continue to be a source of reference 
and inspiration to our writers. In fact, the Tun Seri Lanang Award is specially organized as the highest Literary Award in Singapore to acknowledge writers who have made substantial contributions to the development of literature in Singapore. Throughout the phases of development of the literature in Singapore up till the present, there has been a continuous connection between classical Malay texts and writings in Singapore. Singaporean writers have excavated the roots of Malay literature to discover the history of their race and land to obtain strength and lessons from it, utilizing literature as a vehicle to critically evaluate issues of women, regional and international politics. ${ }^{14}$

Singapore's experience confirms that literary classics can successfully draw the attention of writers from all generations and remain current and relevant for conveying "Singaporean folk tales". This is particularly so for a Malay community struggling considerably with currents of development in city life and a globalized world that is highly sophisticated, actively turning and rapidly changing, to express the rights of women (Malay and Asian), to censure the ruthlessness of world political powers and to defend the rights of societies of the world as a whole.

The connection with classics represents a strong cultural link between the literatures of Singapore and the Malay world, to which classical texts are fundamental, even if writers of each nation and generation give new interpretations and understanding to texts according to the situation in life in individual countries.

\section{COMPARISON OF WORKS}

There is still one other issue that crosses one's mind. What is the position and quality of Singaporean literary works compared to those of Malaysian writers?

In terms of number, it is impossible or at least difficult for Singapore to produce as many works as those of writers in Malaysia. In fact, just the population of Malays in Penang alone, numbering 662782 in 2010, outnumbers the Malay population of Singapore..$^{15}$ It is almost impossible for the Malay community of Singapore, numbering less than half a million, to produce more works than the 17 million Malays in Malaysia, which is approximately 35 times more than in Singapore!

What about the quality of works? To find the answer, a comprehensive and thorough comparative study is necessary. This is perhaps a measure to be explored by scholars from both nations. However, from a general review, I would say that the best of Singaporean writing from various generations is equal to their counterparts in the same movements or fields in Malaysia. 
For example, writers like Muhd Arif Ahmad (MAS), Masuri SN, Noor S.I., Suratman Markasan, A. Ghani Hamid, Mohd Latiff Mohd, Djamal Tukimin, Kalam Hamidy, Nadiputra, Iswardy, Isa Kamari, Djohar Buang and Rohani Din are comparable to Malaysian writers like A. Samad Ahmad, Usman Awang. M. Ghazali \& A.S. Amin, Arenawati, Shahnon Ahmad, A. Latiff Mohidin, A. Samad Said, Baha Zain, Noordin Hassan, Dinsman, Anuar Ridhwan, Azizi Hj Abdullah, Kemala and Khadijah Hashim. Similarly, the younger generation of promising Singaporean writers like Alfian Saat, Rafaat Hamzah, Adlin Alin Mosbit, Saeda Saad, Noor Hasnah Adam, Noridah Kamari, and Munirah Jaafar has potential that can be developed to be on par with the new generation of writers of the region.

However, the area of literary criticism and study in Singapore is somewhat lacking and needs to be fostered. Because this area was introduced at tertiary level quite late compared to Malaysia, it is sluggish. Specific courses in literary criticism were started only in 2001, after the the Bachelor's degree programme in Malay Language and Literature was offered at NIE/NTU. Prior to that, Malay studies was emphasised only at NUS which, in spite of offering courses in classical and modern Malay literature, tended to be in the nature of sociological study. Hopefully the field of literary criticism and literary study can be built up with more postgraduate students from other Singaporean institutions of higher learning such as NTU, NUS and UniSIM.

\section{CONCLUSION-THE ROAR OF LITERARY ASPIRATIONS IN THE WORLD}

The moment of separation between Singapore and Malaysia in 1965 left a profound impression in the hearts and minds of literary writers, activitists and aficionados in Singapore. The sense of loss was the psychological effect of a political development, influencing the content, form and tone of writings after the historical point of 9 August 1965.

Even so, political separation of almost 50 years between the two countries has not severed ties of Malay literature between Singapore and Malaysia, and other parts of the Malay world. Five different forms of links ensure a continuous connection of the literature of the two nations. So far, there is yet no discernible divide between the literature of Singapore and that of Malaysia. On the contrary, there are clear indications of links or ethnic associations between the cultures in the works produced. This is testimony to the veracity of the words and vision of Usman Awang, a literary giant once active in both countries, voiced more than 36 years ago. 
Although the younger generation of writers in Singapore has a very different educational background and post-separation experience from that of their counterparts in Malaysia and Nusantara, there is continuity in the literature produced in these countries as they share common roots. This continuity is the consequence of a kindred spirit that continues to beat in the pulse of Singaporean literature because writers, activists and frontrunners of the language and literature of Singapore possess a keen awareness and will to continue to seek knowledge, discover historical roots, maintain literary ties and contribute equally to the development of literature and culture in a bigger Malay world. This roar of resolve has the support of the authorities in Singapore and has been well-received by counterparts in Malaysia and other countries of the Malay world. God willing, the roar of sheer willpower and the strong bonds of Malay Literature and culture can be maintained as a combined effort to retain the fertile green of the jungle of regional culture for the sake of the survival of the natural beauty of universal humanity.

\section{NOTES}

1 See Usman Awang. "Denyut Nadi Pertemuan Nusantara 1: Tanjung Katong Airnya Tidak Biru" in Dewan Sastera, January 1978.

2 For further discussion on Singapore in classical texts, refer to Hadijah Rahmat, 2002, "Patah Tumbuh Hilang Belum Berganti - Singapura Sebagai Kota Kebangkitan Seni" in SELVES- State of the Arts in Singapore, comp. by Kwok Kian Woon, Arun Mahizan and T. Sasitharan, Hadijah Rahmat (eds.). Singapore: NAC.

3 See Teuku Iskandar, Kesusasteraan Melayu Sepanjang Abad, published by the Malay Studies Department, Brunei University, 1995, p.37.

4 For a more detailed account of the history of printing in Malay, refer to Hadijah Rahmat, 2011, “American Missionary Journey into the Malay Printing World” in Sinha, L. (ed), Rainbows of Malay Literature and Beyond-Festschrift for Professor Md Salleh Yappar. Penang: USM Press, p.103-23.

5 This song was used creatively by Alfian Saat in his short story titled "Singapore By Night", in Malay Sketches, 2012:169-73. The theme of separation was also used in several of his plays such as Causeway, in the book Prisma Pentas published by MBMS in 2004. The song has been a part of the exhibition at Malay Heritage Park at Kampung Gelam, Singapore, since 2012.

6 Watch Aziz Jaafar's performanceathttp://www.youtube.com/watch?v=_dEWyvUtAUM, and Bakri's version at http://www.youtube.com/watch? $\mathrm{v}=7 \mathrm{hWkypoZHkE}$

7 See Mohd Latiff Mohd, 2011. "Bangsaku Di Hari Lahirku” in the Warisan Singapura series published by ASAS' 50 .

8 See FIFTY ON 50, edited by Edwin Thumbo, Isa Kamari, Chia Hwee Pheng and K.T.M. Iqbal, NAC, 2009:119-121.

9 See Mohd Pitchay Gani Mohd Abdul Aziz (ed.), 2005. "Dari Gerhana ke Puncak Purnama- Biografi ASAS 50" in 55 Tahun dalam Persuratan.and http://asas50.com/ 
about/affiliations-and-partners/

10 For complete list of literary works, refer to Rosnani Suni, "Pendidikan Sastera Melayu di Singapura". Master's Thesis, NIE (2004:324).

11 See Suraidi Sipan, 2012. Singapore: Marshall Cavendish Education \& NAC and Saeda Buang, 2013. Begitulah kata-kata. Singapore: Marshall Cavendish \& NAC.

12 See Anthology of ASEAN Literature, The Poetry of Singapore, Edwin Thumboo, Wong Yoon Wah, Lee Tzu Pheng, Masuri SN \& VT Arasu (eds.). Published and sponsored by the ASEAN Committee on Culture and Information, 1985. The project was proposed by the Philipines in 1982 and approved as an ASEAN project on 2 April 1982. See also Modern Literature of ASEAN, by Budi Darma, (ed.). Jakarta: ASEAN Committee on Culture and Information, 2000.

13 See,/Facebook MBMS, https://www.facebook.com/majlis.bahasamelayusingapura?fref-ts; NLhttp:/www.nlb.gov.sg/B, and http://mllpc.sg/page/index.aspx.

14 See Hadijah Rahmat, "Dari Teks Klasik kepada Cerita Rakyat Singapura- Cabaran Sastera Melayu Tradisional di Panggung Jagat" paper presented at the International Seminar themed as "Menuju Kecemerlangan Kebudayaan Jepang dan Asean" organized by Universitas Negeri Surabaya (Unesa), at Sheraton Hotel, Jl. Embong Malang Surabaya, 6-8 December 2004).See also "Kembali Ke Akar Diri: Cabaran Tradisi Dalam Sastera Moden Singapura" in Mengharungi Laut Sastera Melayu, compiled by Jelani Harun and Ben Murtagh, DBP, 2013: 347-371.

15 According to Wikipedia, the number of residents in Penang was 1,520,143in 2010, with $43.6 \%$ Bumiputra, $45.6 \%$ Chinese, $10.4 \%$ Indian and $0.4 \%$ others.

\section{REFERENCES}

Budi Darma, 2000. Modern Literature of ASEAN. Jakarta: ASEAN Committee on Culture and Information.

Juffri Supaat et al., 2011. Bibliografi Sastera Melayu Singapura (1965-2009). Singapore: National Library of Singapore.

Hadijah Rahmat, 2001. "Mengesan jejak Batas Langit Satu Bumi pada 9 Ogos 1965”, paper presented at Seminar Antarabangsa Kesusasteraan Asia Tenggara Kedua organized by DBP, Malaysia.

Hadijah Rahmat, 2002. "Patah Tumbuh Hilang belum berganti - Singapura Sebagai Kota Kebangkitan Seni" in Kwok Kian et al., SELVES - the States of the Arts in Singapore. Singapore:NAC.

Hadijah Rahmat, 2011, "American Missionary Journey into the Malay Printing World" in Sinha, L. (ed), Rainbows of Malay Literature and Beyond - Festschrift in Honour of Professor Md Salleh Yaapar. Penang: USM, p.103-23. Woon, Arun

Mahizan dan T. Sasitharan, Hadijah Rahmat, eds. Singapore: NAC.

Hadijah Rahmat, 2013. "Kembali ke Akar: Cabaran Tradisi dalam Sastera ModenSingapura" in Mengharungi Laut Sastera Melayu/Crossing The Sea of Malay Literature, Esei Penghargaan kepada Profesor Emeritus V.I.Braginsky/ 
Festchrift in Honour of Prof Emeritus V.I.Braginsky, compiled by Jelani Harun and Ben Murtagh. Kuala Lumpur: DBP.

Hadijah Rahmat, 2013. "In Search for Canon of Singapore Malay Poetry: Reflection on Nature, Race, Religion and Love, in Malay Literature 26:1, p.1-17, June 2013. Kuala Lumpur, Malaysia: DBP.

https://www.facebook.com/majlis.bahasamelayusingapura?fref=ts;NLhttp://www. nlb.gov.sg/B,dan http://mllpc.sg/page/index.aspx.

Mohd Latiff Mohd, 2011. "Bangsaku di Hari Lahirku" in Warisan Singapura series. ASAS' 50.

Mohd Pitchay GaniMohd Abdul Aziz, 2005. "Dari Gerhana ke Puncak Purnama Biografi Asas'50" in 55 Tahun Dalam Persuratan. Singapore: Asas'50.

Proudfoot, I., 1993. Early Malay Printed Books-A Provisional Account of Materials in the S'pore-M'sia Area Up To 1920. Kuala Lumpur: University of Malaya.

Shaharuddin Maaruf and Sh. Maznah S.Omar, 2000."Singapore:Malay Literature" in Budi Darma (ed.), in Modern Literature of ASEAN. Jakarta: Asean Committee on Culture and Information.110-119.

Suratman Markasan, 1991. From the Beginning to Two Streams of Social Critique. Dari Jalan Permulaan ke Dua Jalur Kritik Sosial. No publisher.

Teuku Iskandar, 1995. Kesusasteraan Melayu Sepanjang Abad. Brunei: Jabatan Kesusasteraan Melayu, Brunei University.

Thumboo, E., Wong Yoon Wah, Lee Tzu Pheng, Masuri SN \& VT. Arasu (eds.), 1985. Anthology of ASEAN Literature: The Poetry of Singapore. Published and sponsored by the ASEAN Committee on Culture and Information, 1985.

Thumboo E., Isa Kamari, Chia Hwee Pheng and K.T.M. Iqbal, 2009. FIFTY ON 50. Singapore: NAC.

Usman Awang. "Denyut Nadi Pertemuan Nusantara 1: Tanjung Katong Airnya Tidak Biru" in Dewan Sastera, January 1978.

(Translated by Lalita Sinha) 